\title{
Molecular analysis of three novel G6PD variants: G6PD Pedoplis-Ckaro, G6PD Piotrkow and G6PD Krakow ${ }^{\star}$
}

\author{
Monika Maciag ${ }^{1}$, Danuta Plochocka ${ }^{1}$, Ewa Jablonska-Skwiecinska ${ }^{1}$, \\ Ewa Mendek-Czajkowska², Ewa Golaszewska², Wojciech Strojny ${ }^{3}$, \\ Walentyna Balwierz ${ }^{3}$, Ewa Zdebska ${ }^{2}$ and Beata Burzynska ${ }^{1 \bowtie}$ \\ ${ }^{1}$ Institute of Biochemistry and Biophysics, PAS, Warszawa, Poland; ${ }^{2}$ Institute of Hematology and Blood Transfu- \\ sion, Warszawa, Poland; ${ }^{3}$ Department of Pediatric Oncology and Hematology, P-A Institute of Pediatrics, Jag- \\ iellonian University Medical College, Kraków, Poland
}

Received: 19 July, 2007; revised: 03 September, 2007; accepted: 04 September, 2007 available on-line: 08 December, 2007

\begin{abstract}
We present three novel mutations in the G6PD gene and discuss the changes they cause in the 3-dimensional structure of the enzyme: $573 \mathrm{C} \rightarrow \mathrm{G}$ substitution that predicts Phe to Leu at position 191 in the C-terminus of helix $\alpha \mathrm{e}, 851 \mathrm{~T} \rightarrow \mathrm{C}$ mutation which results in the substitution $284 \mathrm{Val} \rightarrow$ $\rightarrow$ Ala in the $\beta+\alpha$ domain close to the C-terminal part of helix $\alpha \mathrm{j}$, and $1175 \mathrm{~T} \rightarrow \mathrm{C}$ substitution that predicts Ile to Thr change at position 392.
\end{abstract}

Keywords: G6PD deficiency, molecular modeling

\section{INTRODUCTION}

Glucose-6-phosphate dehydrogenase (G6PD) is the key enzyme of the pentose phosphate pathway whose main physiological function in red blood cells is to produce NADPH essential for the protection of the cells against oxidative stress. The G6PD gene is X-linked and G6PD deficiency is the most common human enzyme defect, being present in over 400 million people worldwide. Most of the affected people do not complain of the defect. However, they may develop hemolysis after ingestion of fava beans, some drugs or during infection. Neonatal jaundice is often observed in affected families. Chronic nonspherocytic hemolytic anemia (CNSHA) is a rare but more severe clinical type of G6PD deficiency. Anemia and an increased reticulocyte count are persistent throughout the whole life. In some compensated cases there is no anemia but reticulocytosis is still present (chronic nonspherocytic hemolytic disease). Chronic hemolysis may be aggravated by all factors able to provoke hemolysis in asymptomatic G6PDdeficient subjects (Beutler, 1994).

Until now, more than 130 mutations in the G6PD gene have been identified. Most of the mutations detected so far are point mutations causing single amino acid substitutions (Mehta et al., 2000). The three-dimensional structure of human G6PD (mutant Canton) has been determined, so it is possible to establish a structure-function relationship between the identified mutations and the phenotypes of the patients ( $\mathrm{Au}$ et al., 2000).

In this report we describe three new missense mutations in G6PD-deficient patients from three unrelated families.

\section{MATERIALS AND METHODS}

Case description. Family \#1. A 43-year old Georgian male was transfused at the age of 5 because of anemia of unknown etiology. At present, he

\footnotetext{
^ This paper is dedicated to Professor Tadeusz Chojnacki from the Institute of Biochemistry and Biophysics, Polish Academy of Sciences in Warsaw on the occasion of the 50th anniversary of his scientific activity and 75th birthday. Correspondence: Beata Burzynska, Institute of Biochemistry and Biophysics, Polish Academy of Sciences, A. Pawińskiego 5A, 02-106 Warszawa, Poland, phone: (48) 22592 1214, fax: (48) 22658 4636; e-mail: atka@ibb.waw.pl

Abbreviations: Ag, antigen; G6PD, glucose-6-phosphate dehydrogenase; HB, hepatitis B.
} 
Table 1. Hematologic parameters, G6PD activity and molecular data

\begin{tabular}{|c|c|c|c|c|c|}
\hline \multirow[t]{2}{*}{ Patient } & \multicolumn{2}{|c|}{ Family \#1 } & \multicolumn{2}{|c|}{ Family $\# 2$} & \multirow{2}{*}{$\begin{array}{c}\text { Family } \# 3 \\
\text { boy }\end{array}$} \\
\hline & male & his daughter & male & his daughter & \\
\hline Age (years) & 43 & 5 & 40 & 10 & 6 \\
\hline $\mathrm{Hb}(\mathrm{g} / \mathrm{L})$ & 151 & 126 & 147 & 130 & 114 \\
\hline $\mathrm{RBC}\left(\times 10^{12} / \mathrm{L}\right)$ & 4.68 & 4.59 & 4.12 & 4.76 & 3.54 \\
\hline $\mathrm{MCV}(\mathrm{fL})$ & 100 & 82 & 101 & 81 & 91.8 \\
\hline Retics (\% of RBC) & 3.3 & 0.7 & 5.7 & 4.7 & 2.9 \\
\hline Unc Bilir $(\mu \mathrm{mol} / \mathrm{L})$ & 13.6 & 25.4 & 37.8 & 6.0 & 46 \\
\hline $\mathrm{LDH}(\mathrm{U} / \mathrm{L})$ & 247 & 378 & 194 & 223 & 536 \\
\hline Ferritin $(\mu \mathrm{g} / \mathrm{L})$ & 188 & 19.4 & 1595 & 299 & 100 \\
\hline $\mathrm{Fe}(\mu \mathrm{mol} / \mathrm{L})$ & 25 & 28 & 22.4 & 11.3 & 16.5 \\
\hline UIBC $(\mu \mathrm{mol} / \mathrm{L})$ & 40 & 59 & 31.2 & 27.4 & N.D.* \\
\hline G6PD $(\mathrm{IU} / \mathrm{g} \mathrm{Hb})^{* *}$ & 0.0 & 4.2 & 0.0 & 8.34 & 2.6 \\
\hline G6PD mutation & \multicolumn{2}{|c|}{$573 C \rightarrow G$} & \multicolumn{2}{|c|}{$851 \mathrm{~T} \rightarrow \mathrm{C}$} & $1175 \mathrm{~T} \rightarrow \mathrm{C}$ \\
\hline Amino acid substitution & \multicolumn{2}{|c|}{ F191L } & \multicolumn{2}{|c|}{ V284A } & I392T \\
\hline
\end{tabular}

${ }^{*}$ Not determined; **Normal value 13.55 +/- $2.45 \mathrm{IU} / \mathrm{g} \mathrm{Hb}$ according to Beutler (1971).

does not manifest any signs or symptoms of anemia. His blood study revealed an increased reticulocyte count and normal serum bilirubin concentration (Table 1). Erythrocyte G6PD deficiency was diagnosed. The studies were done because of anemia of his nearly 3-year old daughter. She was admitted to the hospital with abdominal pain and jaundice. Her urine was dark and stools were normal. She had no fever. Her liver was palpable $3 \mathrm{~cm}$ below the right costal margin. One day before the onset of the disease she had ingested fava beans. She had had a history of neonatal jaundice with serum bilirubin concentration of $205 \mu \mathrm{mol} / \mathrm{L}$. On admission her blood study revealed anemia $(\mathrm{Hb} 99.5 \mathrm{~g} / \mathrm{L}$, retics 3.2\%) and increased bilirubin concentration (total bilirubin $107.7 \mu \mathrm{mol} / \mathrm{L}$ ). Hepatotropic virus infection (HBV, $\mathrm{HCV}$ ) was excluded. Her recovery was uncomplicated. Four months later her blood study exhibited no anemia, however, her parents noticed a yellow tint of her scleras that occurred intermittently. G6PD deficiency was diagnosed. Results of her latest blood study at the age of 5 are presented in Table 1 .

Family \#2. A 40-year old Polish male had been under medical control since the age of 2 , when a hemolytic crisis in the course of pneumonia developed. A diagnosis of erythrocyte G6PD deficiency was established. After recovery his blood picture was always normal and his physical and mental development were also normal. He kept a diet: he avoided fava beans and other podded plants. He was warned against taking some hemolytic drugs. At the age of 35 he had an acute hemolytic anemia after a Chinese dish containing some pulses. He was admitted to the hospital. His hemoglobin concentration was $100 \mathrm{~g} / \mathrm{L}$, mean cell volume $112 \mathrm{fL}$, total bilirubin $51.3 \mu \mathrm{mol} / \mathrm{L}$ and LDH $790 \mathrm{U} / \mathrm{L}$. HBs Ag and $\mathrm{HCV} \mathrm{Ab}$ were not detected. At present, he has no evident anemia but increased serum bilirubin concentration and reticulocyte count indicate for a mild and almost compensated hemolytic disease (Table 1). His 10-year old daughter has never had anemia or icterus, even during infection and fever, but her reticulocyte count is increased. Her G6PD activity of red cells is decreased (Table 1).

Family \#3. A 6-year old Polish boy had been under medical control since birth. He was transfused at the age of 2 weeks, and then at the age of 2 months due to prominent anemia with jaundice. When the patient was 4 months old, G6PD deficiency was first diagnosed by a semi-quantitative method and was later confirmed quantitatively (Table 1). Since then, he has been under the care of a hematology clinic and had several transient episodes of minor anemia and jaundice, but he did not require transfusion. His physical and mental development was normal. He kept a diet and his parents were warned against giving him hemolytic drugs. At the age of 5 he had an episode of acute hemolytic anemia during viral infection. At the age of 6, during febrile infection, he had hemolytic crisis which resulted in hospitalization and two transfusions. He is currently well and his anemia is almost compensated, however, other laboratory data indicate for a persistent hemolytic process (Table 1).

DNA isolation, amplification and sequencing. Blood samples for this study were obtained after informed consent of the patients. DNA Isolation Kit for Blood/Bone Marrow/Tissue (Roche Diagnostics $\mathrm{GmbH}$, Germany) was used to isolate DNA from leukocytes.

G6PD gene exons 2 to 13 were amplified by polymerase chain reaction (PCR). Each reaction mixture contained 10-250 ng of human genomic DNA, $2.5 \mu \mathrm{l}$ of $10 \times$ PCR buffer, $1.0 \mu \mathrm{L}$ of each primer (10 
A

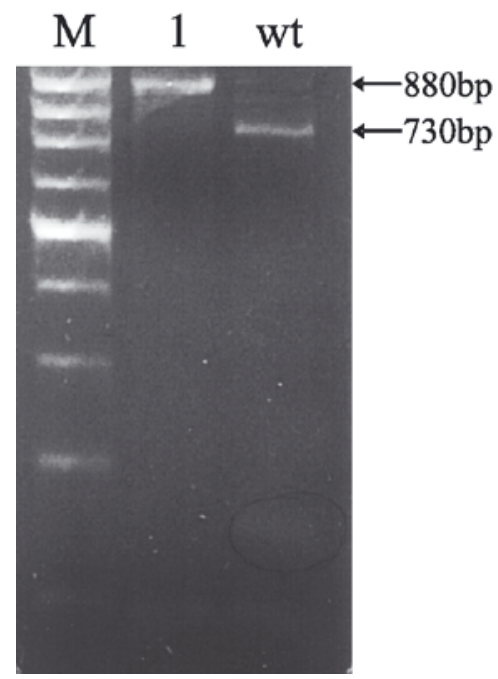

B

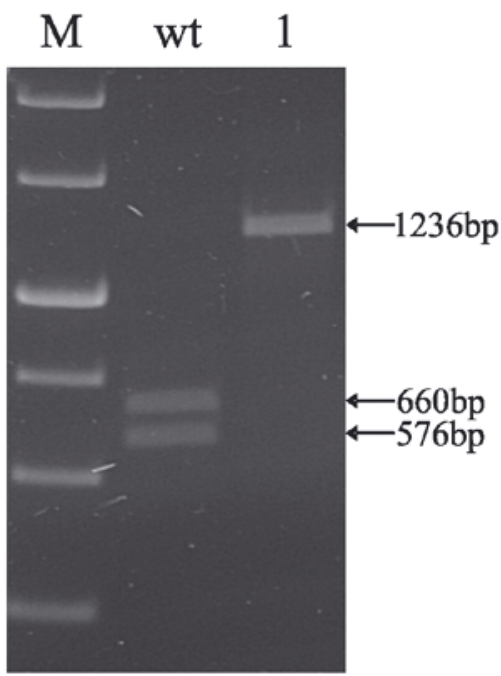

$\mathrm{C}$

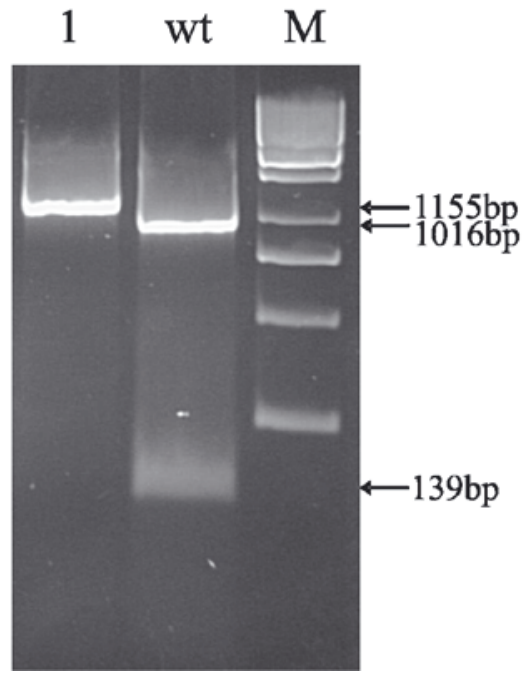

Figure 1. Pattern of restriction enzyme digests of PCR fragments of G6PD.

A, TspGWI digest of PCR fragment containing exons 6, 7 and 8 of G6PD; M, 100 bp ladder; wt, wild type; 1, proband.

B, MboI digest of PCR fragment containing exons 9, 10, 11 and 12 of G6PD; M, 1 kb ladder; wt, wild type; 1, proband.

C, Aat II digest of PCR fragment containing exons 6, 7 and 8 of G6PD; M, 1 kb ladder; wt, wild type; 1, proband.

$\mathrm{pmol} / \mu \mathrm{L}$ ) and 1 unit of enzyme (FastStart Taq DNA Polymerase, Roche Diagnostics $\mathrm{GmbH}$, Germany) in a final volume of $25 \mu \mathrm{L}$. PCR was carried out using Mastercycler personal (Eppendorf) with 3-min denaturation step at $94^{\circ} \mathrm{C}$, followed by 30 cycles of $45 \mathrm{~s}$ at $94^{\circ} \mathrm{C}, 45 \mathrm{~s}$ of annealing in the temperature appropriate for the primers, then the elongation at $72^{\circ} \mathrm{C}$ of appropriate time, and the final 5-min extension at $72^{\circ} \mathrm{C}$. PCR products were analyzed by agarose gel electrophoresis. The sequences of all primers and the annealing temperatures are available upon request.

DNA fragments generated by PCR amplification were purified using Qiaquick PCR Purification Kit (QIAGEN, Germany), and directly sequenced with BigDye Terminators and the appropriate primers using an ABI Prism 377 sequencer (Applied Biosystem, CA, USA). Restriction analysis with the use of TspGW1 (EURx), AatII (Fermentas) and $M b o I$ (Fermentas) enzymes was carried out to confirm the presence of the detected mutations (Fig. 1). PCR products $\left(15 \mu \mathrm{L}\right.$ ) were digested at $70^{\circ} \mathrm{C}$ (for the Tsp GW1 enzyme) and $37^{\circ} \mathrm{C}$ (for AatII and MboI) for $3 \mathrm{~h}$.

Molecular model of human G6PD structure. The three-dimensional structure of human G6PD (the mutant Canton R459L) has been determined (Au et al., 2000). To check the influence of the F191L, V284A and I392T mutations on the enzyme structure, models of the wild type and mutated proteins were obtained by simple replacement of Leu459 to Arg and Leu459 to Arg together with Phe191 to Leu, Val284 to Ala, or
Ile392 to Thr, respectively (Fig. 2). The wild type and mutated structures were subjected to energy minimization in vacuo using CVFF forcefield as implemented in DISCOVER ver. 2004.1 (Accelrys, San Diego, USA).

\section{RESULTS}

Direct sequencing of the G6PD gene from the Georgian male revealed the presence of a previously undescribed $573 \mathrm{C} \rightarrow \mathrm{G}$ mutation located in exon 6 which resulted in a phenylalanine to leucine substitution at position 191. The presence of this mutation was confirmed with the restriction enzyme Tsp GW1 (Fig. 1A).

DNA sequencing of the G6PD gene from the Polish male showed another novel mutation located in exon 8 . The $851 \mathrm{~T} \rightarrow \mathrm{C}$ substitution predicts a valine to alanine change at position 284 . The presence of this mutation was verified with the restriction enzyme AatII (Fig. 1B).

DNA sequencing of the G6PD gene from the Polish boy revealed the presence of a previously undescribed $1175 \mathrm{~T} \rightarrow$ C substitution located in exon 10, predicting an isoleucine to threonine substitution at position 392. The presence of this mutation was confirmed with the restriction enzyme MboI (Fig. 1C).

No other mutations were detected in the remaining exons or adjacent regions of the G6PD gene. The novel variants F191L, V284A and I392T were named G6PD Pedoplis-Ckaro, G6PD Piotrkow 

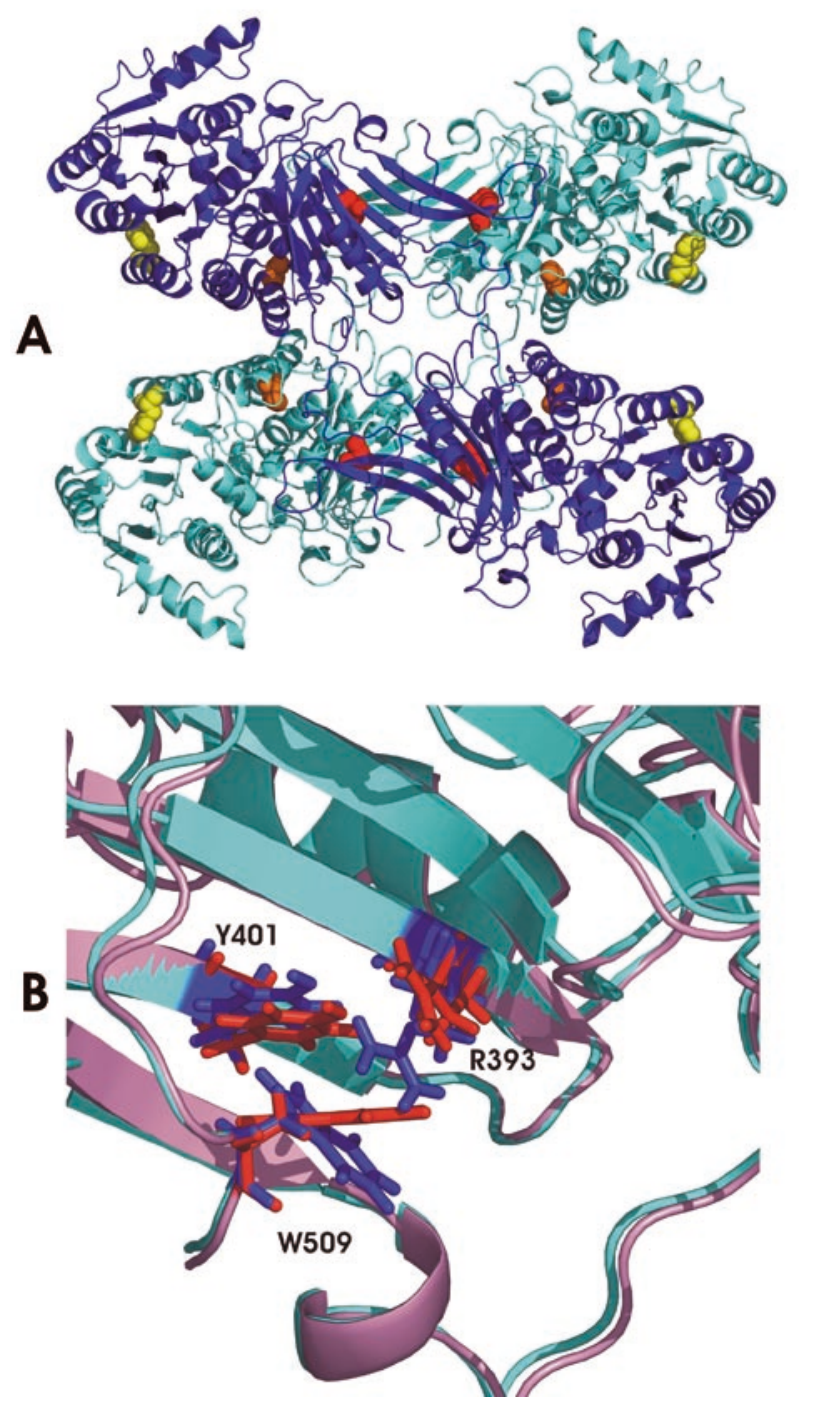

Figure 2A. Ribbon representation of human G6PD, according to the crystal structure of the Canton mutant, PDB entry 1QKI (Au et al., 2000).

Subunits of the enzyme are shown in dark and light blue. F191, colored yellow; V284, orange and I392, red are shown as spheres.

Figure 2B. Changes in the structure of human G6PD induced by I392T mutation.

Wild type of human G6PD is shown as pink ribbon with R393, Y401 and W509 (sticks, colored in red). Ribbon of the mutated enzyme is shown in light blue; R393, Y401 and W509 in dark blue.

and G6PD Krakow, respectively, after the patients' place of origin.

\section{DISCUSSION}

All the novel variants described belong to class I, since all three patients have chronic hemolysis. The patient with G6PD Pedoplis-Ckaro has a chronic nonspherocytic hemolytic disease without anemia. Hemolysis is more intensive in the patient with G6PD Piotrkow. His reticulocyte count is higher than that of the first patient and the compensation of hemolysis is not quite full. His serum ferritin concentration is high, probably as a result of intensive iron absorption stimulated by increased erythropoiesis in the bone marrow. However, the hemolytic process in both patients is mild. They lead normal life, both are married and professionally active. The boy with G6PD Krakow and chronic nonspherocytic hemolytic anemia has had frequent exacerbation of hemolysis provoked mainly by infections. Nevertheless, one should evaluate his hemolytic process also as a mild one.

F191 is located at the C-terminus of helix $\alpha \mathrm{e}$ (Fig. 2A), outside the coenzyme binding site, far away from the dimer and tetramer interfaces. Two mutations adjacent to F191: H155N and N165D have been described earlier, and are recognized as class I and class II variants, respectively (Tang et al., 1992; Menounos et al., 2000). Known mutations located at helix $\alpha$ e have been classified as class I variants: S179C, D176G and class II variants: S188F and D181V (Vulliamy et al., 1988; Beutler et al., 1991; Hirono et al., 1994; Beutler et al., 2002). F191 is not a highly conserved residue. The environment of this residue is hydrophobic, so replacement of the Phe by Leu, which is not much smaller, should not significantly affect the overall protein fold. This is confirmed by the energy minimization calculations for the wild type enzyme and the F191L mutant.

V284 is located in the $\beta+\alpha$ domain close to the C-terminal part of helix $\alpha \mathrm{j}$ (Fig. 2A). Helix $\alpha \mathrm{j}$ contains E287 and K290 forming salt bridges with K290 and E287, respectively, located in the neighbouring subunit. These contacts stabilize tetramer formation. Several known mutations in the proximity of V284 are classified as the class I variants: G274K, P276S, S278F, S278P and G447R, some as class II or class III variants: T279A, T279S, R285C, R285H, S448G, Q449H and D282H (Vulliamy et al., 1988; De Vita et al., 1989; Viglietto et al., 1990; Beutler et al., 1992; Calabro et al., 1993; Mason et al., 1995; Xu et al., 1995; Miwa et al., 1996; Okano et al., 2001; Taki et al., 2001; Beutler et al., 2002). Changes in this region may have an effect on the tetramer interface, which is mainly made by electrostatic contacts. The V284A substitution neither changes the polarity of the amino-acid residue nor introduces a steric hindrance. A comparison of the minimized structures of the wild type and V284A mutant showed minor changes in the course of the main chain and no changes in the positions of the residues forming salt bridges, so this mutation does not cause serious structure distortions. 
I392 is located in the $\beta+\alpha$ domain at $\beta$-sheet $\mathrm{L}$ far away from the dimer interface (Fig. 2A). The side chain of 1392 is directed away from the $\mathrm{NADP}^{+}$crevice, so it does not interfere directly with the NADP ${ }^{+}$ binding site. On the other hand, energy minimization calculations show that the introduction of I392T mutation could change the orientation of residues R393, Y401 and W509 (Fig. 2B), which are in direct contact with the nicotinamide moiety of $\mathrm{NADP}^{+}$. This could influence protein function.

\section{Acknowledgements}

This work was supported by a grant from the State Committee for Scientific Research, Warszawa, Poland (PBZ-MIN-015/P05/2004; PBZ-KBN-122 P05/2004/03/02).

\section{REFERENCES}

Au SWN, Gover S, Lam VMS, Adams MJ (2000) Structure 8: 293-303.

Beutler E (1971) Grune and Stratton. New York, London.

Beutler E (1994) Blood 11: 3613-3636.

Beutler E, Vulliamy TJ (2002) Blood Cells Mol Dis 28: $93-$ 103.

Beutler E, Kuhl W, Saenz GF, Rodriguez W (1991) Hum Genet 87: 462-464.

Beutler E, Gelbart T, Miller W (2002) Blood Cells Mol Dis 28: 104-107.
Beutler E, Westwood B, Kuhl W, Hsia YE (1992) Hum Hered 42: 327-329.

Calabro V, Mason PJ, Filosa S, Civitelli D, Cittadella R, Tagarelli A, Martini G, Brancati C, Luzzatto L (1993) Am J Hum Genet 52: 527-536.

De Vita G, Alcalay M, Sampietro M, Cappelini MD, Fiorelli G, Toniolo D (1989) Am J Hum Genet 44: 233-240.

Hirono A, Miwa S, Fujii H, Ishida F, Yamada K, Kubota K (1994) Blood 83: 3363-3368.

Mason PJ, Sonati MF, MacDonald D, Lanza C, Busutil D, Town M et al. (1995) Blood 85: 1377-1380.

Mehta A, Mason PJ, Vulliamy TJ (2000) Baillieres Best Pract Res Clin Haematol 13: 21-38.

Menounos P, Zervas C, Garinis G, Doukas C, Kolokithopoulos D, Tegos C, Patrinos GP (2000) Hum Hered 50: 23741. Erratum in: Hum Hered (2000) 50: 383.

Miwa S, Fujii H (1996) Am J Hematol 51: 122-132.

Okano Y, Fujimoto A, Miyagi T, Hirono A, Miwa S, Niihira S, Hirokawa H, Yamano Y (2001) Eur J Pediatr 160: 105-108.

Taki M, Hirono A, Kawata M, Den M, Kurihara Y, Shimizu H, Yamada K, Fujii H, Miwa S (2001) Int J Hematol 74: 153-156.

Tang TK, Huang CS, Huang MJ, Tam KB, Yeh CH, Tang CJ (1992) Blood 79: 2135-2140.

Viglietto G, Montanaro V, Calabro V, Vallone D, D'Urso M, Persico MG, Battistuzzi G (1990) Ann Hum Genet 54: $1-15$.

Vulliamy TJ, D’Urso M, Battistuzzi G, Estrada M, Foulkes NS, Martini G et al. (1988) Proc Natl Acad Sci USA 85: 5171-5175.

Xu W, Westwood B, Bartsocas CS, Malcorra-Azpiazu JJ, Indrak K, Beutler E (1995) Blood 85: 257-263. 